Notre Dame Law Review

Volume 94 | Issue 1

Article 6

$11-2018$

\title{
Due Process, Free Expression, and the Administrative State
}

Martin H. Redish

Northwestern University Pritzker School of Law

Kristin McCall

Northwestern University Pritzker School of Law

Follow this and additional works at: https://scholarship.law.nd.edu/ndlr

Part of the Administrative Law Commons, Constitutional Law Commons, and the First Amendment Commons

Recommended Citation

94 Notre Dame L. Rev. 297 (2018).

This Article is brought to you for free and open access by the Notre Dame Law Review at NDLScholarship. It has been accepted for inclusion in Notre Dame Law Review by an authorized editor of NDLScholarship. For more information, please contact lawdr@nd.edu. 


\title{
DUE PROCESS, FREE EXPRESSION, AND THE
}

\section{ADMINISTRATIVE STATE}

\author{
Martin H. Redish* E Kristin McCall** \\ The history of American freedom is, in no small measure, \\ the history of procedure.
}

-Justice Felix Frankfurter ${ }^{1}$

\section{INTRODUCTION}

Procedural due process is, by its nature, a conditional protection. It does not guarantee that government will be unable to deprive an individual of her liberty, her property, or even her life. Instead, it does nothing more than impose the condition that government may deprive an individual of any or all of these valuable interests only if certain procedural requirements have first been satisfied. But it would not be an overstatement to assert that this constitutional protection serves as an important element of the foundation of a democratic system. As a matter of political theory, the implicit social contract between government and citizen in a liberal democratic state demands that the government treat its citizens with dignity and respect. If government seeks to take away a citizen's liberty or property for violation of law, the social contract therefore demands that government provide the citizen with a full and fair opportunity to challenge the allegations of legal wrongdoing; anything less would be inconsistent with its contractual obligations toward its citizens. Of all the procedural requirements dictated by the demands of fair procedure, far and away the most important is the requirement of an independent, neutral adjudicator. Absent a truly neutral adjudicator, provision

(C) 2018 Martin H. Redish \& Kristin McCall. Individuals and nonprofit institutions may reproduce and distribute copies of this Article in any format at or below cost, for educational purposes, so long as each copy identifies the authors, provides a citation to the Notre Dame Law Review, and includes this provision in the copyright notice.

* Louis and Harriet Ancel Professor of Law and Public Policy, Northwestern University Pritzker School of Law. The authors would like to thank Adam Alexander of the class of 2019 and Emily Burger of the class of 2020 at Northwestern University Pritzker School of Law for their valuable research assistance. An earlier version of this Article was supported by and delivered at a conference sponsored by the Center for the Study of the Administrative State, Antonin Scalia Law School, George Mason University. However, the views expressed are solely those of the authors.

** AB Yale University; JD Northwestern University.

1 Malinski v. New York, 324 U.S. 401, 414 (1945) (separate opinion). 
of any and all other procedural protections will be all but meaningless, since a biased or unduly influenced adjudicator is capable of ignoring all procedural protections in reaching a decision.

As important as procedural due process is in any case in which an individual's life, liberty, or property is at stake, special procedural considerations come into play when the liberty in danger of revocation is the individual's First Amendment right to speak. The First Amendment right of free expression is simultaneously foundational to the continued viability of American democracy and among the most fragile of all constitutional protections. Even when the right to communicate is vigorously protected, it takes courage to express one's views, and that courage is often easily lost at the first sign of even the slightest governmental intimidation or threat. It is therefore not surprising that both jurists and commentators have recognized a special category of procedural protection, known as "First Amendment 'due process." "2 This refers to the requirement that a would-be speaker be provided with procedures that satisfy the constitutional requirements of procedural due process before a claim of First Amendment protection for his expression may be rejected. The best way to view First Amendment due process is as a necessary but not sufficient condition. In other words, rejection of a claim of First Amendment protection absent the provision of the requisite procedures ${ }^{3}$ will automatically be deemed unconstitutional. However, the mere fact that such procedural protections have been provided will not automatically be deemed to satisfy the requirements of First Amendment protection. In addition, the determination of whether the expression in question is constitutionally protected must satisfy the substantive requirements of First Amendment jurisprudence.

Due process in general, and First Amendment due process in particular, face perhaps their most serious threat in the context of the modern administrative state. When viewed through the lens of procedural due process, the fundamental structure of the adjudicatory process takes on a very differentand much more ominous-tenor in the administrative context than in the traditional judicial setting. In the traditional judicial setting, adjudication is presided over by mostly independent judges who have no particular interest who wins or loses the case. In sharp contrast, in the administrative setting adjudication is conducted and resolved by employees-often high-ranking employees-of the very agency whose existence is justified by the need for regulation and which has decided to institute the particular regulatory proceeding in the first place. Such potential sources of threat to adjudicatory neutrality and independence would never be tolerated in the judicial system. Indeed, given applicable precedent, it seems quite clear that such aberrations from adjudicatory neutrality would be deemed unconstitutional as violations of the Fifth or Fourteenth Amendment's guarantee of procedural due pro-

2 See Henry P. Monaghan, First Amendment "Due Process," 83 Harv. L. Rev. 518, 518 (1970).

3 What those requisite procedures actually are will be discussed in detail subsequently. See infra Part III. 
cess. Yet to say these aberrations are commonplace in the administrative process would be an understatement. Indeed, they represent the fundamental characteristics of the modern administrative process. On the basis of a poorly reasoned Supreme Court decision feebly attempting to distinguish between the due process limits imposed on judicial and administrative adjudication, however, at least for the present time, the highly dubious constitutionality of the modern administrative process is largely ignored. ${ }^{4}$

Some would no doubt argue that it is too late in the day to bring about so dramatic a constitutional upheaval within the administrative state, and as a practical and descriptive matter, at least, this is likely true. Some would also likely respond that whatever threats to due process values that occur regularly in the administrative state are more than justified by the regulatory benefits to society that flow from its existence. This view we vehemently reject. There is no reason the administrative state cannot operate both effectively and fairly. Indeed, to the extent the goal of procedural due process is thought to be the utilitarian value of accurate decisionmaking, ${ }^{5}$ fair adjudication by a truly neutral adjudicator would seem essential to both effectiveness and fairness. Overregulation is no better for society than underregulation, and the danger of overregulation increases dramatically when the adjudicator begins the process with a built-in preference for the position taken by the very agency of which she is a part. We could avoid many of the due process dangers of selfinterested adjudication simply by substantially increasing both the independence and decision-making power of administrative law judges.

One need not bring about so dramatic an upheaval in the administrative process in order to substantially rectify many of the serious due process problems that plague the modern administrative state. It is possible to view the due process pathologies of the administrative state on different levels of constitutional harm. Of course, if one were to accept our due process attack on the fundamental operation of the administrative process, this multileveled analysis would be unnecessary; the process, as currently constituted, would be invalidated. But, assuming for the moment that our foundational due process attack will be viewed as a bridge too far, it is important to recognize that there are especially harmful constitutional pathologies that are confined to much narrower forms of the administrative process.

Instead of invalidating all administrative adjudication on due process grounds, one could conceivably seek out legal contexts in which the threat to administrative adjudicatory neutrality is greatest. For example, when a constitutional challenge is presented to the agency's regulatory authority, either facially or as applied to the particular regulatory context, the constitutional stakes are raised significantly. From one perspective, the neutrality of an interested adjudicator is placed under even greater stress than when the issue for adjudication is simply whether a regulated party has or has not violated a regulation. When issues of constitutionality are raised, the challenge gives

4 See Withrow v. Larkin, 421 U.S. 35 (1975); see also infra text accompanying notes 91-117.

5 See, e.g., Mathews v. Eldridge, 424 U.S. 319, 348-49 (1976). 
rise to a threat to the future scope of the agency's authority-one that would likely make any individual whose professional existence is intimately intertwined with the agency's power feel protective of that power. From another perspective, the most foundational considerations involve constitutional challenges to agency action. It is therefore especially in such cases that the neutrality and independence of the adjudicator are most important.

Will an adjudicator tied to a specific agency be incapable of deciding neutrally in all cases? Likely not. But the foundation of adjudicatory independence is the assumption that we choose to overprotect independence by establishing ex ante categorical rules, rather than risk underprotecting it through use of a case-by-case inquiry into neutrality. In many instances, the adjudicator herself will fail to recognize her implicit biases. It is for these reasons that due process is appropriately deemed to require use of categorical prohibitions on identification between the adjudicator and the enforcing entity. And, for reasons already mentioned, the need for such prophylactically insulated neutrality is at its most intense in the case of a constitutional challenge to agency action or authority.

As important as adjudicatory neutrality is in the case of any constitutional challenge to agency authority, for reasons already noted the need for such independence is arguably at its height when the constitutional challenge is grounded in the First Amendment right of free expression. It is for this very reason that the concept of "First Amendment due process" has been developed. First Amendment due process, then, must add an element above and beyond the level of constitutional protection afforded by procedural due process alone. What the content of that element actually is, however, is not immediately clear. This Article seeks to answer this question by examining First Amendment due process in the specific context of the federal government's administrative state. In this sense, it involves a synthesis of First Amendment doctrine and theory with an analysis of procedural due process in the administrative context.

Claims of First Amendment protection may well clash with administrative regulatory schemes. At the state level, for example, such claims potentially clash with either state or local administrative zoning schemes or censorial boards created to limit or prohibit the distribution of obscene movies or publications. More important today, however, are the federal administrative regulatory schemes that may clash with claims of commercial speech protection. For example, when the Federal Trade Commission attempts to regulate, punish, or halt allegedly false advertising, the advertiser may seek to challenge the allegation that its advertising is false, thereby triggering First Amendment protection for its advertisements. When the Food and Drug Administration attempts to prevent, stop, or punish so-called "off-label" advertising-i.e., advertising of a prescription drug for uses for which the drug was not originally approved ${ }^{6}$ - the pharmaceutical company may wish

6 See Coleen Klasmeier \& Martin H. Redish, Off-Label Prescription Advertising, the FDA and the First Amendment: A Study in the Values of Commercial Speech Protection, 37 Aм. J.L. \& MED. 315, 315 (2011). 
to challenge the constitutionality of such a regulatory scheme under the First Amendment. ${ }^{7}$ It is true that historically, commercial speech has received considerably less First Amendment protection than more traditionally protected categories of free expression. ${ }^{8}$ But both theoretically and doctrinally, this situation has changed dramatically in recent years. ${ }^{9}$ The Supreme Court has wisely recognized that the constitutional stakes in the regulation or suppression of commercial speech are quite high, and that governmental restrictions on commercial expression can cause serious harm to traditionally recognized First Amendment interests. ${ }^{10}$

In both state and federal contexts, the first question that the doctrine of First Amendment due process poses is whether the administrative regulatory framework, in the first instance, satisfies the requirements of procedural due process for the adjudication of the regulated party's First Amendment claim. The concept of First Amendment due process raises the following questions about administrative adjudication of First Amendment challenges to the administrators' regulation or suppression of expression: (1) Can administrative adjudication ever satisfy the requirements of due process under such circumstances? (2) If not, does the provision of an opportunity for some form of judicial review of the administrative determination satisfy due process guarantees? Our answer to both questions is no.

The conclusions we reach in this Article are multileveled. On the firstor what could be called the foundational-level, we conclude that under no circumstances may regulatory administrative adjudication, as currently structured, be deemed to satisfy the requirements of procedural due process, much less the stronger requirements of First Amendment due process. ${ }^{11}$ Procedural due process, at its foundation, demands a neutral adjudicator. Absent a neutral adjudicator, other procedural protections are rendered all but meaningless, for a biased adjudicator is likely to ignore the evidence in any event. ${ }^{12}$ Our analysis will demonstrate that the modern administrative adjudicatory structure fails to satisfy this foundational requirement.

On a second level, should our foundational first-level conclusion be rejected on grounds of impracticality, we believe that, at the very least, a prophylactically insulated adjudicator-of a type not seen in our current administrative structure-is required to resolve a constitutional challenge to

7 Cf. United States v. Caronia, 703 F.3d 149, 168-69 (2d Cir. 2012) (concluding that the government cannot prosecute pharmaceutical companies "for speech promoting the lawful, off-label use of an FDA-approved drug," but limiting its holding to those FDAapproved drugs for which off-label use is not prohibited).

8 See, e.g., Valentine v. Chrestensen, 316 U.S. 52, 54 (1942).

9 See Martin H. Redish, Money Talks: Speech, Economic Power, and the Values of Democracy 16-18 (2001) (describing steady increase in Supreme Court protection of commercial speech post-1986).

10 See, e.g., Greater New Orleans Broad. Ass'n v. United States, 527 U.S. 173 (1999); 44 Liquormart, Inc. v. Rhode Island, 517 U.S. 484 (1996); Rubin v. Coors Brewing Co., 514 U.S. 476 (1995).

11 See infra Part II.

12 See infra Section II.B. 
agency authority or actions. The inherent predisposition (if only on a subconscious level) of regulators to resist externally imposed limits on the exercise of their own powers renders them constitutionally incapable of judging the constitutionality of the exercise of their power to regulate. ${ }^{13}$

On a third level, we believe that when the constitutional challenge is grounded in the First Amendment right of free expression, the procedural assurances of adjudicatory neutrality need to be made even stronger. In non-free speech cases, the due process problem could arguably be solved simply by providing for de novo judicial review of agency action. When free speech rights are at stake, however, we believe that judicial review post-administrative adjudication, in anything but the most emergent situations, fails to satisfy the special requirements of First Amendment due process. In such situations, serious harm to constitutionally protected free speech interests may result from the interim restraints imposed until the judicial review mechanism will be in a position to remove the restraint on expression imposed at the administrative level. Moreover, requiring a subject of regulation to bear the costs and burdens of the administrative adjudicatory process before being able to have its First Amendment claim heard by a truly neutral adjudicator may well chill that subject's willingness to raise its constitutional challenge. In short, because of the simultaneous fragility and constitutional significance of free speech rights, a party challenging the constitutionality of administrative regulation under the First Amendment right of free expression must be permitted to circumvent the administrative process and immediately present the First Amendment challenge in court. We fully recognize the inconsistency of our proposal with current doctrine. Indeed, we write this Article in the hope of stimulating a rethinking, if not an outright change in that doctrine.

The potential availability of judicially imposed preliminary restraint, issued following the administrative determination and prior to judicial review, on enforcement of the administrative directive regulating, suppressing, or punishing private expression seems theoretically to provide a conceivable safety valve. On closer examination, however, such a possibility is likely to prove to be less than effective, for several reasons. Initially, at the very start of an appellate proceeding, at a point at which the reviewing court is largely unfamiliar with the complex constitutional issues involved, the likelihood of deference to administrative expertise will be great. This is simply a practical reality. Moreover, once the regulatory body has found against the would-be speaker, the speaker's incentive to invest in pursuing the matter further may often be chilled at the point where review is to be sought.

Because of these serious constitutional difficulties, we believe that First Amendment due process dictates (1) a categorical exclusion of the regulatory body from any consideration of a First Amendment challenge to its regulatory authority, and (2) an opportunity for a litigant to bring its constitutional challenge directly to the federal courts, once a regulator has

13 See infra Section II.D. 
decided to seek to suppress speech. To be sure, this is not the current procedure. ${ }^{14}$ But it is our view that current procedure has been developed without sufficient regard to the constitutional imperative of First Amendment due process.

The first Part of this Article will explore the theoretical foundations of procedural due process, focusing particularly on the essential due process requirement of a neutral adjudicator. ${ }^{15}$ We will follow that discussion with an analysis of the extent to which administrative adjudication of constitutional challenges to its regulatory authority or decisions satisfies the demands of procedural due process. ${ }^{16}$ After concluding that administrative regulators categorically fail to satisfy the requirements of due process, at least in the context of constitutional challenges to their regulatory authority, we will explain why the availability of post-administrative judicial review cannot cure the constitutional defect in administrative adjudication of First Amendment challenges to its regulatory authority. ${ }^{17}$ Finally, we will consider the extent to which modern administrative procedure authorizes the process that we deem constitutionally essential to enable the subject of administrative regulation to present its First Amendment challenge at a meaningful point in the process. $^{18}$

\section{Neutral Adjudication and the Theory of Procedural Due Process}

\section{A. Neutral Adjudication as a Necessary Condition of Procedural Due Process}

There has never been a clear consensus as to the underlying theoretical framework of procedural due process. The conflict has been grounded in a debate between those who favor an "instrumental" rationale and those who prefer to employ a "noninstrumental" rationale. Those who adopt a noninstrumental rationale have framed their reasoning in terms of a "dignitary" theory, which focuses due process on the need to preserve and facilitate the individual's dignity within a liberal democratic society. ${ }^{19}$ The Supreme Court, on the other hand, has employed a form of utilitarian-or instrumental-calculus, designed to balance the need for an accurate decision, the practical stakes for the litigants, and the burdens imposed on government. ${ }^{20}$ But whatever theory of procedural due process one chooses to adopt, ${ }^{21}$ it is clear that the sine qua non of that constitutional protection is the availability

14 See infra subsection II.B.2.

15 See infra Part I.

16 See infra Part II.

17 See infra Part III.

18 See infra Section II.B.

19 See Jerry L. Mashaw, Essay, Administrative Due Process: The Quest for a Dignitary Theory, 61 B.U. L. Rev. 885, 886 (1981).

20 See Connecticut v. Doehr, 501 U.S. 1, 10-11 (1991); Mathews v. Eldridge, 424 U.S. 319, 348-49 (1976).

21 For a detailed analysis of both the utilitarian and dignitary theories of procedural due process, see Martin H. Redish \& Lawrence C. Marshall, Adjudicatory Independence and the Values of Procedural Due Process, 95 Yale L.J. 455, 468-91 (1986). 
of a neutral adjudicator. As far back as the early $1600 \mathrm{~s}$, at the time of $\mathrm{Dr}$. Bonham's Case, ${ }^{22}$ the proposition that no man can be a judge in a case in which he has a financial interest was firmly established, and for good reason. Unless the adjudicator can be considered truly neutral between the parties, the provision of all other traditional due process guarantees is rendered meaningless. What difference would it make, for example, that a litigant has the right to call witnesses on her behalf or to cross-examine her antagonists, if the adjudicator's ultimate decision will not be based on the evidence presented, but rather on the basis of extraneous prejudices or biases?

At least in the judicial context, ${ }^{23}$ the Supreme Court has consistently adhered to the proposition that neutral adjudication represents the foundation of procedural due process. For example, in Tumey v. Ohio ${ }^{24}$ the Court held unconstitutional an Ohio statute that designated half of any criminal fine imposed by a mayor's court to go to the township, municipality, or county that prosecuted the case. The local community in Tumey passed an ordinance that the Mayor would receive his costs from the village's share. ${ }^{25}$ There was no evidence that the Mayor had actually taken his financial interest into account in deciding any of the cases. Seemingly recognizing that actual influence could only rarely be proven and further recognizing the importance of the appearance of fairness, the Court established a generalized, prophylactic standard of adjudicatory neutrality. ${ }^{26}$ And as one of us wrote many years ago, "[t]he legal standard in Tumey-"possible temptation to the average man as a judge'-has not been seriously disputed." 27 The very words of this standard, which has been applied consistently by the Court, ${ }^{28}$ suggest its highly demanding quality. There need be no showing of actual wrongdoing; rather, existence of merely a "possible temptation" to decide a case on the basis of factors other than a fair analysis of the evidence suffices to render the adjudicator insufficiently neutral for due process purposes. Thus, the Court has wisely adopted a prophylactically protective standard of neutrality: it is willing to overprotect adjudicatory independence, rather than risk underprotecting it. But this standard does not, by itself, inform us of what actually constitutes a "possible temptation." We therefore turn to an attempt to categorize the different forms of constitutionally impermissible interferences with adjudicatory neutrality.

22 (1610) 77 Eng. Rep. 646; 8 Co. Rep. 113b.

23 As will be seen, the Court has—rather mysteriously—been much more trusting of administrative adjudicators than of judicial ones. See infra Section II.C.

24273 U.S. 510 (1927).

25 Id. at 519.

$26 I d$. at 532 ("Every procedure which would offer a possible temptation to the average man as a judge to forget the burden of proof required to convict the defendant, or which might lead him not to hold the balance nice, clear and true between the State and the accused, denies the latter due process of law.").

27 Redish \& Marshall, supra note 21, at 495.

28 See, e.g., Aetna Life Ins. Co. v. Lavoie, 475 U.S. 813, 825 (1986); Ward v. Village of Monroeville, 409 U.S. 57, 60 (1972). 
In this Section, we propose a taxonomy of biases that should be deemed to give rise to the same level of potential bias exhibited in all of the cases in which the Court has previously found the neutral adjudicator principle to have been violated. ${ }^{29}$ This taxonomy of biases should be employed to determine whether the bias potential in a given case violates the due process-dictated neutral adjudicator requirement. We conceptualize three categories of the constitutionally impermissible prelitigation interests that encapsulate the biases recognized in the Court's prior cases and present problems for due process. We have termed these three categories (1) coercive interference, (2) incentivized decisionmaking, and (3) associative or disassociative prejudices. If any of these biases are present, then the threat to adjudicatory neutrality rises to an unconstitutional level and the judge's involvement in the adjudication must therefore be found to violate due process.

\section{B. A Taxonomy of Unconstitutional Adjudicatory Biases}

\section{Coercive Interference}

Coercive interference occurs when one of the parties or an outside individual or entity attempts to threaten or intimidate the adjudicator, thereby creating the potential for undue influence on the judge's decisionmaking. The potential for bias in this situation-i.e., that the judge is likely to be influenced by the coercive party to decide the case in the way that party would like-is high.

An extreme example of such coercive interference arguably occurred in Ecuador in Republic of Ecuador v. Chevron Corp. ${ }^{30}$ In Chevron, the government of Ecuador allegedly actively supported the Lago Agrio plaintiffs in seeking redress against Chevron for alleged illegal polluting. ${ }^{31}$ After President Correa was elected President of Ecuador, defendants claimed that he "openly campaigned for a decision against Chevron, at the same time that the Government made clear that any judge who issued opinions contrary to the Government's interests would be subject to dismissal and even possible criminal prosecution." 32 This is an extreme situation, but it exemplifies the potential problem with coercive interference: a judge cannot be neutral if he is being coerced to find a certain way.

\section{Incentivized Decisionmaking}

Incentivized decisionmaking describes a situation in which an adjudicator is aware that she will gain a benefit from the outcome of the decision. In

29 See infra Section II.B.

$30 \quad 638$ F.3d 384 (2d Cir. 2011).

31 Id. at 390.

32 Claimants' Notice of Arbitration If 38, Chevron Corp. v. Republic of Ecuador, UNCITRAL, PCA Case No. 2009-23, http://www.chevron.com/documents/pdf/Ecuador BITEn.pdf. 
such a situation, the judge may have an incentive to decide the case in favor of a certain party, despite the fact that the evidence would dictate a contrary conclusion, so that she can gain a personal or associational benefit. If an adjudicator stands to gain a benefit from the outcome of the decision, the Due Process Clause has been violated. Indeed, Tumey stands as a perfect illustration of this category. In Tumey, the Mayor was paid for each conviction, ${ }^{33}$ giving him an incentive to convict defendants whether they deserved it or not. In Aetna Life Insurance Co. v. Lavoie, ${ }^{34}$ the judge stood a chance to gain a better outcome in his pending cases against other insurance companies based on the rule of decision applied in the case before him. Although the judge did not stand to get a direct financial gain, the potential beneficial effect on his pending cases may have created an incentive to him to rule one way. In both of these cases, the bias clearly rose to an unconstitutional level.

It should be emphasized that the adjudicator need not be consciously influenced by the incentive or disincentive. This underscores the prophylactic nature of the neutrality protection. Because the judge herself may not be aware that her decision is being influenced by the incentive or disincentive, and because the legitimacy of the system turns as much on the appearances of fairness as the reality, the neutrality directive is properly construed to err on the side of overprotection.

The benefit to the adjudicator need not be personal. It could also be an associational benefit, as it was in Ward $v$. Village of Monroeville, where the Mayor stood to gain a financial benefit for his city if the defendants were fined. ${ }^{35}$ This was not a direct financial benefit to the Mayor, but overall he stood to benefit indirectly from the outcome of each case because of his interest in maintaining the city's coffers. The associational benefit could also be reputational rather than financial. A hypothetical example would be if a judge works on the board of a group whose reputation could be helped or harmed by the outcome of the decision of a case. The judge would gain a benefit if she found in favor of the group because the group would gain a better reputation or avoid getting a worse one. Regardless of the nature of the benefit, in all of these scenarios the judge has an incentive outside the evidence to decide the case in a specific way, creating an unconstitutional level of bias potentiality.

\section{Associative and Disassociative Prejudices}

Finally, an association or disassociation with one of the parties in the case gives rise to a constitutionally unacceptable potential for bias. Associative and disassociative prejudices occur when some factor connects the judge to one side of the case, either favorably (associative) or unfavorably (disassociative). For example, associative prejudice would arise if a judge's family member is one of the parties, so the judge might be predisposed to rule in

33 See Tumey v. Ohio, 273 U.S. 510, 520 (1927).

34 See Aetna Life Ins. Co. v. Lavoie, 475 U.S. 813, 822-24 (1986).

35 See Ward v. Village of Monroeville, 409 U.S. 57, 58 (1972). 
favor of that party. An example of a disassociative prejudice can be seen in In re Murchison. ${ }^{36}$ There the Supreme Court held that due process is violated when the judge who issued the contempt citation for actions taking place in his courtroom adjudicates the trial for contempt. ${ }^{37}$ In such a situation, the judge already has a negative attitude toward the defendant based on his earlier interactions with him in his courtroom.

Associative and disassociative prejudices carry a high risk of bias in the outcome of the case because the judge consciously or subconsciously risks being influenced by his connection with or feelings toward one of the parties in the case, wholly apart from the case's internal merits. As the Court reasoned in In re Murchison, a judge with such a connection to one of the parties "cannot be, in the very nature of things, wholly disinterested in the conviction or acquittal of those accused" because "[w] hile he would not likely have all the zeal of a prosecutor, it can certainly not be said that he would have none of that zeal." 38

The potential for violations of impartiality in adjudications involving associative or disassociative prejudices is demonstrated by reference to the theory of motivated reasoning. ${ }^{39}$ Motivated reasoning is the idea that "[p] eople are more likely to arrive at those conclusions that they want to arrive at." 40 The use of the word "want" is somewhat misleading, however. It suggests that a person consciously chooses the end result or conclusion and then does everything to achieve that result. This is not necessarily the case. Put another way, motivated reasoning "refers to the tendency of people to unconsciously process information-including empirical data, oral and written arguments, and even their own brute sensory perceptions-to promote goals or interests extrinsic to the decisionmaking task at hand." 41 Motivated reasoning therefore prevents individuals from making dispassionate, impartial, and fair judgments. ${ }^{42}$

Motivated reasoning operates through two mechanisms. The first is known as "biased search," in which individuals are more likely to search for information in a selective manner, focusing their inquiry on data that supports their group, belief, or position than information that challenges it. ${ }^{43}$ The second mechanism is known as "biased assimilation," in which individu-

36 See In re Murchison, 349 U.S. 133 (1955).

37 See id. at $135,139$.

$38 \quad I d$. at 137.

39 Motivated reasoning also applies to a lesser extent to incentivized decisionmaking and coercive interference. In both situations, a judge may perceive facts in a light most favorable to the outcome they subconsciously desire based on the potential benefit or the coercion. However, it seems more likely that a judge may be more conscious of the bias in these situations, in which case motivated reasoning would no longer apply because the judge would be consciously searching for a way to reach the desired outcome.

40 Ziva Kunda, The Case for Motivated Reasoning, 108 Psychol. Bull. 480, 495 (1990).

41 Dan M. Kahan, Foreword: Neutral Principles, Motivated Cognition, and Some Problems for Constitutional Law, 125 Harv. L. REv. 1, 7 (2011).

42 See id.

43 See id. at 21. 
als are likely to credit or dismiss evidence or argument selectively based on how it conforms to their group, belief, or position. ${ }^{44}$ Biased assimilation also includes the danger that individuals will credit individuals within their group with greater knowledge and therefore greater credibility than outsiders. ${ }^{45}$

It is important to note that motivated reasoning has its limitations. Generally, people will generally not believe anything they want simply because that belief furthers their interests. Assuming they are seeking to act in good faith, individuals will not make up evidence or irrational arguments to support their interests. The concern, rather, is that they will selectively seek out evidence that supports their interest or weigh such evidence more heavily. As a result, motivated reasoning is extremely dangerous to the goal of fair adjudication because it prevents people from realizing that their reasoning is biased and instead allows them to believe that their beliefs are fair and objective. ${ }^{46}$ In the case of a judge, the judge may well believe she was deciding a case fairly and impartially even though she was really viewing the evidence in a light more favorable to one of the parties. This means that a judge exhibiting motivated reasoning would exhibit a strong bias potentiality.

\section{Administrative Adjudication and Due Process}

Although due process has primarily been applied to the traditional judicial court system, it is well established that due process also applies in the context of administrative adjudication. ${ }^{47}$ The traditionally applied test may play a lesser role in administrative adjudications due to the utilitarian nature of the Court's procedural due process balancing test, ${ }^{48}$ but because adjudicatory neutrality serves as the foundation of procedural due process, the requirement of a neutral adjudicator must still be satisfied in administrative proceedings. ${ }^{49}$ In the judicial context, the Court has consistently held that an overlap in investigatory, prosecutorial, and adjudicatory powers creates a bias potentiality that violates due process. ${ }^{50}$ However, in administrative adjudication the heads of an agency are generally empowered to function as adjudicators and make final agency decisions while also serving investigatory and

\footnotetext{
44 See id.

45 See id.

46 See Eileen Braman \& Thomas E. Nelson, Mechanism of Motivated Reasoning? Analogical Perception in Discrimination Disputes, 51 Aм. J. Pol. Scr. 940, 940-41 (2007).

47 See Richardson v. Perales, 402 U.S. 389 (1971); Goldberg v. Kelly, 397 U.S. 254 (1970).

48 See Mathews v. Eldridge, 424 U.S. 319, 348-49 (1976).

49 See Goldberg, 397 U.S. at 271 ("And, of course, an impartial decision maker is essential.").

50 See In re Murchison, 349 U.S. 133, 137 (1955) ("Having been a part of [the accusatory] process a judge cannot be, in the very nature of things, wholly disinterested in the conviction or acquittal of those accused."); Tumey v. Ohio, 273 U.S. 510, 534 (1927) ("A situation in which an official perforce occupies two practically and seriously inconsistent positions, one partisan and the other judicial, necessarily involves a lack of due process of law in the trial of defendants charged with crimes before him.").
} 
prosecutorial roles. ${ }^{51}$ In this Part, we will describe the federal administrative adjudicatory process. Then, we will demonstrate that the power of agency commissioners to overturn Administrative Law Judge (ALJ) decisions and make the final agency decision violates the neutral adjudicator requirement imposed by procedural due process.

\section{A. The Federal Administrative Adjudicatory Process}

The federal administrative adjudicatory process varies among agencies. Generally, the procedure each federal agency follows is determined by a synthesis of the agency's organic act and the Administrative Procedure Act (APA). Although traditionally applied due process requirements for the most part still apply to agencies, the APA was enacted in part to offer additional protections beyond the minimum constitutional requirements of due process. ${ }^{52}$ However, these protections are only triggered when the agency's organic act contains specific language requiring compliance with formal APA procedures. $^{53}$ In order to ensure impartial adjudications, the APA forbids "[a]n employee or agent engaged in the performance of investigative or prosecuting functions for an agency" to "participate or advise in the decision, recommended decision, or agency review." 54 Despite this protection from an overlap in conflicting powers, the APA creates an exception for "the agency or a member or members of the body comprising the agency" from this prohibition. ${ }^{55}$ This means that the head of an agency or any of its commissioners may participate in the investigative or prosecutorial functions of the agency while also serving in an adjudicatory role.

Commissioners of each agency are often empowered to serve in investigatory and prosecutorial roles within their respective agency. For example, the Federal Trade Commission (FTC) can begin an investigation "by the Commission upon its own initiative." 56 Once the investigation is completed, the Commission votes on whether grounds exist to issue a complaint. If so, an adjudicative proceeding is initiated. ${ }^{57}$ FTC complaint counsel, made up of staff from the Bureau of Consumer Protection or a regional office of the FTC, conduct the prosecution on behalf of the Commission before an ALJ. ${ }^{58}$

51 See, e.g., 5 U.S.C. $\$ 556$ (b) (2012) (stating that the heads of an agency can adjudicate hearings).

52 See Alfred C. Aman, Jr. \& William T. Mayton, Administrative Law \$ 8.1, at 200-02 (1998).

$53 I d . \S 8.2$, at $202-03$.

545 U.S.C. $\$ 554(d)$.

$55 I d$.

5616 C.F.R. $\$ 2.1$ (2018). The "Commission," which is composed of five members, refers to the Commissioners of the FTC. See id. $\$ 0.1$.

57 See id. $\$ 3.11$.

58 See A Brief Overview of the Federal Trade Commission's Investigative and Law Enforcement Authority, Fed. TrAdE Comm'N, http://www.ftc.gov/about-ftc/what-we-do/enforcementauthority (last modified July 2008). 
The prosecution is conducted on behalf of the Commission, assumedly with their oversight.

The Securities and Exchange Commission (SEC) provides another example of the permissible synthesis of administrative, investigative, and prosecutorial powers. An administrative proceeding in the SEC begins when the SEC's Division of Enforcement staff conducts an investigation into a potential violation of federal securities laws. ${ }^{59}$ If the Enforcement Division determines that a violation has occurred, it presents its findings to the Commission and recommends that the Commission bring a civil action before an ALJ. ${ }^{60}$ If the Commission agrees that a violation has occurred, it files an order instituting proceedings, in which it directs an ALJ to conduct a public administrative proceeding and issue an Initial Decision. ${ }^{61}$ The SEC may seek a variety of sanctions from the ALJ, including disgorgement of ill-gotten gains, civil penalties, censures, and cease and desist orders. ${ }^{62}$ In these proceedings, the Commission is represented by attorneys from the Division of Enforcement. ${ }^{63}$ Like in the FTC, these attorneys prosecute the cases on behalf of the Commission. ${ }^{64}$ Thus, in the SEC, the Commission also decides whether to initiate formal proceedings, has the power to initiate proceedings, and oversees the prosecution.

The heads of each agency are also empowered to adjudicate hearings and make final agency decisions. The APA dictates that in formal proceedings the head of an agency or an ALJ adjudicates formal hearings and makes the initial decision. ${ }^{65}$ In some agencies, this is the final decision, but in most agencies, the parties-including the agency, if it is a party-can appeal to a panel of judges in the agency or to the head of the agency. ${ }^{66}$ This means that the agency itself can appeal an initial decision that is unfavorable to the agency and then overturn the initial decision in favor of the agency.

The FTC provides a good example of the nature of the adjudicatory authority exercised by the Commissioners. In FTC adjudications, an ALJ conducts the formal hearing. ${ }^{67}$ Either party, including the FTC, may appeal the initial decision to the full Commission. ${ }^{68}$ The Commission receives

59 See About the Division of Enforcement, U.S. Sec. \& Exchange Comm'n, https://www.sec .gov/enforce/Article/enforce-about.html (last modified Aug. 2, 2007).

60 See How Investigations Work, U.S. Sec. \& Exchange Comm'n, http://www.sec.gov/ News/Article/Detail/Article/1356125787012\#.VEcMQT7wIhE (last modified Jan. 27, 2017). The "Commission" refers to the five Commissioners of the SEC. See 17 C.F.R. $\S 200.10$ (2018).

61 See Office of Administrative Law Judges, U.S. SEc. \& Exchange Comm'n, http://www .sec.gov/alj\#.VEcLBD7wIhF (last modified Jan. 26, 2017).

62 See How Investigations Work, supra note 60.

63 See About the Division of Enforcement, supra note 59.

$64 I d$.

655 U.S.C. $\$ \S 556(\mathrm{~b}), 557$ (b) (2012).

66 See id. $\$ 557(\mathrm{~b})$.

67 A Brief Overview of the Federal Trade Commission's Investigative and Law Enforcement Authority, supra note 58.

$68 I d$. 
briefs, holds oral arguments, and issues its own final decision and order. ${ }^{69}$ "The $[\mathrm{C}]$ ommission has the authority to 'adopt, modify, or set aside' the ALJ's initial decision" in making its final decision. ${ }^{70}$ This final decision is then appealable to a federal circuit court of appeals. ${ }^{71}$ The circuit court may review the final decision under the substantial evidence standard, as section 5(c) of the FTC Act, which states "the findings of the Commission as to the facts, if supported by the evidence, shall be conclusive," has been interpreted as analogous to the substantial evidence standard of the APA. ${ }^{72}$

The SEC adjudicatory process functions similarly to the FTC adjudicatory process. After the Commission files an order instituting proceedings, an ALJ conducts a public hearing and issues an initial decision. ${ }^{73}$ Once the ALJ issues that decision, either party, including the SEC, may appeal to the Commission, which performs a de novo review and can affirm, reverse, modify, set aside, or remand for further proceedings. ${ }^{74}$ The Commission's opinion constitutes the final agency decision of the SEC unless the initial decision is not appealed, in which case the initial decision is the final agency decision. That decision is reviewable by a federal court of appeals. ${ }^{75}$

Not all heads of agencies serve a role in the adjudicatory process. For example, in the Food and Drug Administration (FDA), an ALJ adjudicates the initial hearing ${ }^{76}$ and those appeals are heard by the Department Appeals Board of the Department of Health and Human Services ("DHHS"). ${ }^{77}$ The Department Appeals Board consists of civil servants appointed by the DHHS Secretary who are meant to provide an impartial and independent review of the dispute. ${ }^{78}$ Unlike the SEC appeals process, the standard of review for the Department Appeals Board is substantial evidence for issues of fact and clear error for issues of law. ${ }^{79}$ The Commissioner of the FDA has no role in issuing initial or final agency decisions. However, the examples of the FTC and SEC demonstrate that the APA and many agency organic acts enable agency

$69 I d$.

703 West's Federal Administrative Practice $\$ 3352$ (2018) (quoting 16 C.F.R. $\$ 3.54(c)(2018))$.

71 See id. $\$ 3354$ (citing 15 U.S.C. $\$ 45$ (c) (2012)).

72 Id. (quoting 15 U.S.C. $\$ 45(c)$ ) (citing 5 U.S.C. $\$ 706(2)$ (E) (2012)).

73 See Office of Administrative Law Judges, supra note 61.

74 See id.

75 Id.

7621 C.F.R. $\$ \S 17.3,17.19,17.45$ (2018) (although an ALJ will be the adjudicator for all Civil Money Penalty hearings before the FDA, other types of hearings may implicate the Commissioner of the FDA directly).

$77 \quad$ Id. $\$ 17.47$.

78 DAB Divisions, U.S. Dep't Health \& Hum. Servs., https://www.hhs.gov/about/ agencies/dab/about-dab/divisions/index.html (last updated Sept. 13, 2016). The Department Appeals Board consists of five board members, most of whom have worked for the DHHS or the Board prior to serving as board members. None of the current board members worked for the FDA. See Who Are the Board Members E J Judges?, U.S. Dep'T Health \& Hum. SERvs., http://www.hhs.gov/dab/about/members/judges.html\#board (last updated Aug. 10, 2018).

79 See 21 C.F.R. $§ 17.47(\mathrm{k})$. 
commissions to serve investigatory, prosecutorial, and adjudicatory roles in the same matter. As we will discuss in the next Section, this overlap in roles creates a bias potentiality that violates the neutral adjudicator principle.

\section{B. The Neutral Adjudicator Principle Applied to Administrative Adjudication}

As already noted, while due process has primarily been applied to the judicial system, it is well established that due process also applies to administrative adjudications. ${ }^{80}$ After all, the Due Process Clause protects citizens against government's improper deprivation of property rights, and it cannot be disputed that administrative agencies exercise governmentally authorized coercive power to deprive private actors of their property. Regardless of the other procedures that due process requires in administrative hearings, an impartial adjudicator serves as a threshold requirement in administrative proceedings. ${ }^{81}$ In its cases applying due process to the judicial system, the Supreme Court has consistently held that due process is violated if a judge also serves in a partisan role in the same case. ${ }^{82}$ Applying this rule to the administrative adjudicatory process described in the previous Section, it is clear that the power of agency commissioners to participate in investigations, prosecutions, and adjudications creates an impermissible bias in contravention of the dictates of due process.

One of the reasons the commissioners' roles in adjudications threaten due process is that it undermines the perception of fairness of administrative adjudications, which is one of the dignitary interests due process is meant to protect. The commissioners are the heads of the agency. In fact, they are referred to as "The Commission" in the cases of the FTC and SEC, meaning that as a body they represent the agency. Regardless of whether the commissioners are actually biased, the other parties to the action may perceive bias. The commissioners are too closely tied to the agency itself and to the investigation and prosecution of each case for the people to perceive them as fair and unbiased judges. The administrative adjudicatory process cannot function properly if participants in the process cannot trust that it is fair and balanced.

The overlap in investigatory, prosecutorial, and adjudicatory roles performed by commissioners also violates the neutral adjudicator principle as stated in Tumey and its progeny. First, the commissioners' position as heads of their agency automatically places them in a partisan role inconsistent with the impartiality by which they are constitutionally bound. Like the mayorjudge in Tumey, the commissioners are the leaders of their respective agencies. In Tumey, the Supreme Court found that the Mayor's dual role as mayor

80 See, e.g., Richardson v. Perales, 402 U.S. 389 (1971); Goldberg v. Kelly, 397 U.S. 254 (1970).

81 Goldberg, 397 U.S. at 271 ("And, of course, an impartial decision maker is essential.").

82 See, e.g., Ward v. Village of Monroeville, 409 U.S. 57 (1972); In re Murchison, 349 U.S. 133 (1955); Tumey v. Ohio, 273 U.S. 510 (1927). 
and judge violated due process because "[a] situation in which an official perforce occupies two practically and seriously inconsistent positions, one partisan and the other judicial, necessarily involves a lack of due process of law in the trial of defendants charged with crimes before him." 83 The commissioners also occupy both partisan and judicial positions: as heads of the agency and representatives of the agency in all matters, commissioners clearly occupy a partisan position in favor of the agency, and they are also empowered to adjudicate initial hearings and make final agency decisions. These two conflicting positions cannot be reconciled: when the agency is a party, agency officials prosecute the case on behalf of the commissioners, making the commissioners a party to the case. Thus, under Tumey, this overlap in roles unambiguously violates due process.

The commissioners' role in the investigatory and prosecutorial processes also gives rise to potential bias. In Murchison, the judge had effectively functioned as grand jury in the contempt hearing before serving as judge in the same case. The Court stated that " $[\mathrm{h}]$ aving been a part of [the accusatory] process a judge cannot be, in the very nature of things, wholly disinterested in the conviction or acquittal of those accused" because "[w] hile he would not likely have all the zeal of a prosecutor, it can certainly not be said that he would have none of that zeal." 84 Commissioners are involved in the agency's accusatory process: they oversee the investigations conducted by their agencies, review the evidence collected, and decide whether to initiate formal proceedings. Throughout this whole process, they examine the case through the lens of a prosecutor. As heads of the agency, they are constantly attempting to determine if a party violated their rules and regulations. It is true that when they take on the role of judge, they may not have the same prosecutorial zeal that they may have had earlier in the process, but like the Murchison Court found, it cannot be said that the commissioners "would have none of that zeal." Thus, the potential for bias due to the overlap in accusatory and adjudicatory roles violates due process.

Application of the taxonomy of biases to the administrative adjudicatory process, specifically those of the FTC and SEC, also demonstrates that the overlap in investigatory, prosecutorial, and adjudicatory powers of commissioners creates an impermissible level of bias potentiality that violates the neutral adjudicator principle. ${ }^{85}$ There exists at least a small risk of coercive interference in the administrative adjudication context. Because the commissioners are appointed by the executive and ultimately serve as part of the executive branch, a situation could arise in which they may be pressured by the executive to carry out more prosecutions or to be harder on white-collar crime. This could put pressure on commissioners to find against more defendants lest they lose their appointments in those agencies in which commissioners can be dismissed for cause. More problematic, however, is the

83 Tumey, 273 U.S. at 534 (citing City of Boston v. Baldwin, 1 N.E. 417 (Mass. 1885); State ex rel. Colcord v. Young, 12 So. 673 (Fla. 1893)).

84 Murchison, 349 U.S. at 137.

85 See supra Section II.A. 
fact that administrative adjudications currently exhibit both associative and disassociative prejudices. The commissioners who make the final decisions in many of these agencies are members of the agency itself, meaning they have an associative connection to one of the parties (at least in those cases in which the agency is a party) and are thus inherently predisposed to view the agency more favorably. Moreover, the commissioners' role in investigations and prosecutions creates a disassociative prejudice towards the party sought to be regulated. Commissioners often sign off on investigations and decisions to proceed, and oversee regulatory proceedings generally, meaning they may also look unfavorably upon the parties charged because of facts learned outside of the hearing. By deciding whether to initiate proceedings against a party, the commissioners have already made a determination that there is probable cause (or some similar weight of evidence) to initiate proceedings. Similar to the judge in Murchison, the commissioners may be predisposed to believe the parties charged are guilty because they initially viewed the evidence through a prosecutorial or adversarial lens.

Motivated reasoning represents a real danger in the context of the administrative adjudicatory process. Because they are a part of their respective agencies, commissioners begin with an attachment (or at least a perceived attachment) to their agency, which is often a party in a regulatory proceeding. This attachment is likely to give rise to subconscious motivated reasoning. Motivated reasoning may cause the commissioners to seek out information that supports the agency's case and to credit the agency's arguments and evidence more than those of the opposing side, both of which eliminate the possibility of an impartial, fair adjudication. These problems are amplified because the commissioners may have already played a role by deciding whether to initiate proceedings. This means that the commissioners have already examined the evidence through the agency's lens, weighed the evidence on behalf of the agency, and determined that the evidence merited further action. ${ }^{86}$ Moreover, because motivated reasoning is usually subconscious, the commissioners would never recognize that their association with the agency influences their decisions, and thus their motivational reasoning cannot be corrected. This is especially a problem when the challenge to regulatory authority is grounded in the First Amendment right of free expression. As one of us has written: "Nonjudicial administrative regulators of expression exist for the sole purpose of regulating; this is their raison d'être. ... [I]f only subconsciously, [they] will likely feel the obligation to justify their existence by finding some expression constitutionally subject to

86 Cf. Williams v. Pennsylvania, 136 S. Ct. 1899 (2016) (concluding that due process was violated when a state supreme court justice refused to recuse himself in an appeal from a murder conviction, even though he had been the district attorney at the time the prosecution was filed). 
regulation." 87 Professor Emerson put the point more bluntly in discussing censorship agencies: "[T] he function of the censor is to censor." 88

Will it always be the case that a regulator will possess an inherent instinct, conscious or subconscious, to favor regulation? Probably not. Indeed, conservative Presidents generally opposed to regulation may well choose to appoint administrators who favor deregulation. The point, however, is that in the individual instance no one can know for sure. In the judicial context, the Supreme Court has wisely held that the due process-based demand for neutral adjudication cannot be satisfied by an individualized inquiry into an adjudicator's bias. ${ }^{89}$ Rather, the Court finds factors that it deems ex ante to be disqualifying. Where we cannot be certain of possessing perfect knowledge in the individual case, due process requires that we risk erring on the side of overprotection, rather than underprotection. Thus, while there is no inherent reason to believe that the commissioners necessarily act with bias merely because of their role within the agency, due process and its neutral adjudicator requirement are concerned not only with actual judicial wrongdoing, but also with the possibility or appearance of bias. $^{90}$ As we have demonstrated, commissioners potentially exhibit all three categories of unconstitutional bias, and definitely exhibit associative prejudice due to their connection to the agency and their role in the accusatory process. This bias potentiality violates the neutral adjudicator principle.

\section{Withrow v. Larkin and the Supreme Court's Flawed Defense of Administrative Adjudication}

As we have shown, the association of investigatory, prosecutorial, and adjudicatory powers within agencies such as the FTC and SEC gives rise to the potential for unconstitutional bias that should, as a logical matter, contravene due process's neutral adjudicator requirement established in cases involving judges such as Tumey and Murchison. However, when the Supreme Court has been asked to apply the neutral adjudicator requirement in the administrative context, it has categorically rejected any due process challenge to the absence of complete adjudicatory independence. In its 1975 decision in Withrow v. Larkin, the Supreme Court addressed the question of whether a state administrative board's authority to investigate claims, present charges, rule on those charges, and impose punishment on parties violates due pro-

87 Martin H. Redish, The Proper Role of the Prior Restraint Doctrine in First Amendment Theory, 70 VA. L. REv. 53, 76-77 (1984).

88 Thomas I. Emerson, The Doctrine of Prior Restraint, 20 Law \& Contemp. Probs. 648, 659 (1955).

89 See Caperton v. A.T. Massey Coal Co., 556 U.S. 868, 881 (2009) ("The Court asks not whether the judge is actually, subjectively biased, but whether the average judge in his position is 'likely' to be neutral, or whether there is an unconstitutional 'potential for bias.").

90 See, e.g., Tumey v. Ohio, 273 U.S. 510, 532 (1927) ("Every procedure which would offer a possible temptation to the average man as a judge . . not to hold the balance nice, clear, and true between the State and the accused, denies the latter due process of law.”). 
cess. $^{91}$ The case involved a doctor who performed abortions in Milwaukee and was under investigation by the Wisconsin Medical Examining Board ("the Board") for alleged violations of state licensing requirements. ${ }^{92}$ The Board held an investigative hearing to determine whether the doctor had engaged in certain prohibited acts. ${ }^{93}$ This was followed by a final hearing to specifically determine whether the doctor had violated the state statute by practicing medicine under a different name than that under which he was originally licensed, by permitting an unlicensed physician to perform abortions at his clinic, and by splitting fees. ${ }^{94}$ At this final hearing the Board found probable cause to revoke the doctor's medical license. ${ }^{95}$ The Board was empowered by statute to conduct investigations, temporarily suspend medical licenses, and institute criminal actions or actions to revoke a doctor's license. ${ }^{96}$ The doctor challenged the constitutionality of the statute as a violation of procedural due process. ${ }^{97}$ Applying the neutral adjudicator dictate from Tumey and Murchison, the district court found that the Board's involvement in the investigation and the final adjudication violated due process, stating, "for the board [to] temporarily . . . suspend [the doctor's] license at its own contested hearing on charges evolving from its own investigation would constitute a denial to him of his rights to procedural due process." 98 The court reasoned that, "[i]nsofar as [the statute] authorizes a procedure wherein a physician stands to lose his liberty or property, absent the intervention of an independent, neutral and detached decision maker, we concluded that it was unconstitutional and unenforceable."99

The Supreme Court rejected the district court's reasoning. The Court held that "the combination of investigative and adjudicative functions does not, without more, constitute a due process violation." 100 According to the Court, due process is violated when "the probability of actual bias on the part of the judge or decisionmaker is too high to be constitutionally tolerable."101 The Court stated that this combination of functions does not necessarily create an unconstitutional risk of bias. ${ }^{102}$ The Court pointed to the variety of functions the members of administrative agencies are often called upon to perform, including "to receive the results of investigations, to approve the

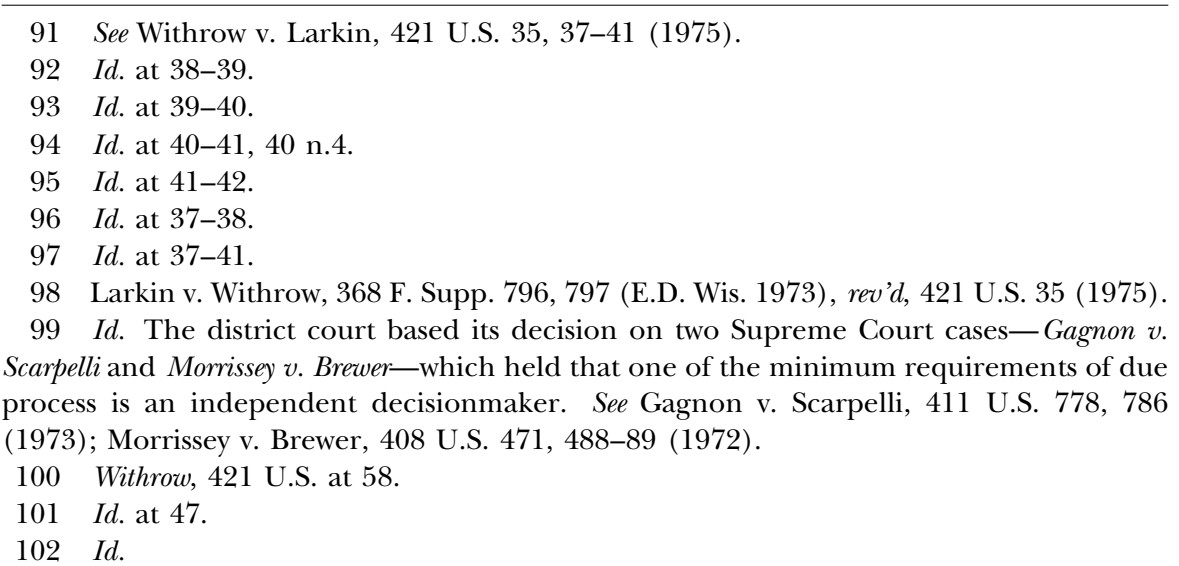


filing of charges or formal complaints instituting enforcement proceedings, and then to participate in the ensuing hearings." 103 The Court found that "[t] his mode of procedure does not violate the Administrative Procedure Act, and it does not violate due process of law."104 The Court reasoned that:

The risk of bias or prejudgment in this sequence of functions has not been considered to be intolerably high or to raise a sufficiently great possibility that the adjudicators would be so psychologically wedded to their complaints that they would consciously or unconsciously avoid the appearance of having erred or changed position. ${ }^{105}$

In support of its conclusion, the Court noted that Congress had already dealt with the issue of combining investigative and adjudicatory powers through the APA, seemingly implying that Congress had deemed this overlap of powers permissible. ${ }^{106}$ The APA provides that no employee who investigates or prosecutes may participate or provide advice in the adjudicatory process; though, as noted previously, the APA expressly exempts "the agency or a member or members of the body comprising the agency" from this prohibition. ${ }^{107}$ The exemption allows the Commissioners to engage in the investigation, prosecution, and adjudication of claims. The Court failed to address how the Commissioners' direct role in all three processes might be impacted by due process, though the opinion implies that this is permissible.

Wholly apart from the fact that the APA has no applicability or relevance whatsoever to state administrative procedures, the Court's decision in Withrow flies in the face of its due process decisions in the judicial context. In so doing, the Court established two separate due process standards-one for judges and one for administrators. Yet the Due Process Clause "entitles a person to an impartial and disinterested tribunal in both civil and criminal cases." 108 As it had many years earlier in Tumey, the Court explained in Marshall $v$. Jerrico, Inc. that this constitutionally protected entitlement ensures "that no person will be deprived of his interests in the absence of a proceeding in which he may present his case with assurance that the arbiter is not predisposed to find against him."109 This directly contradicts the Court's decision in Withrow some five years earlier: the commissioners in agencies such as the FTC and SEC authorize the initial investigation against a party, issue the complaint, control the prosecution, and then adjudicate any appeals filed by either party. As in the judicial context, the commissioners' role in the investigation and prosecution at the very least creates an appearance that the commissioners are predisposed to find against the party whom they investigated and prosecuted, especially since earlier in the proceeding they had a prosecutorial mindset and believed the defendants were liable.

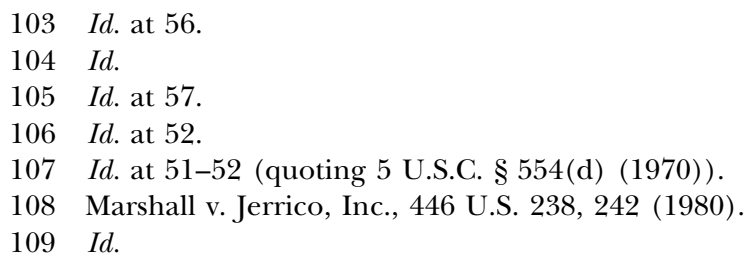


And yet the Court in Withrow apparently found this practice to be consistent with due process.

One of the reasons the Withrow Court asserted in support of the constitutionality of this overlap of powers in the administrative context was that there is a "presumption of honesty and integrity in those serving as adjudicators," and therefore the Court must be convinced that "under a realistic appraisal of psychological tendencies and human weakness, conferring investigative and adjudicative powers on the same individuals poses such a risk of actual bias or prejudgment that the practice must be forbidden . . ."110 The Court's statement, however, contradicts the reasoning of the Tumey Court in the judicial context fifty years earlier. In Tumey, the Court did not care that some of the judges might not be affected by the bias, or in the words of the Withrow Court, that many judges exhibit honesty and integrity. Instead, in Tumey the Court invoked the very opposite presumption, holding that " $[\mathrm{t}] \mathrm{he}$ requirement of due process of law in judicial procedure is not satisfied by the argument that men of the highest honor and greatest self-sacrifice could carry it on without danger of injustice."111 And yet in Withrow the Court implied that we now presume that administrative adjudicators have the "highest honor and greatest self-sacrifice." It is truly bizarre that the Court would assume that administrators, with all of the reasons to question their inherent objectivity, will act without prejudice while at the same time assuming that judges may well not do so. At the very least, there is no justification for distinguishing between the two-on what possible basis could one assume that adjudicators are more likely to be free from prejudice than judges? But more importantly, for reasons previously noted, a strong case can be made that exactly the opposite is true, especially in cases involving challenges to the constitutionality of agency action or authority.

That the Court in Withrow drew a wholly unjustified distinction between the levels of neutrality required in judicial and administrative proceedings is demonstrated by how it attempted to distinguish its earlier decision in Murchison. The Court in Withrow attempted to distinguish the case before it from Murchison in two ways. First, the Court stated, "Murchison has not been understood to stand for the broad rule that the members of an administrative agency may not investigate the facts, institute proceedings, and then make the necessary adjudications." 112 The Court's meaning in this passage is clear: administrative law is different and normal due process requirements do not apply to it. Unfortunately, the Court had the situation completely reversed: it is the administrative context in which adjudicatory neutrality must be more suspect. ${ }^{113}$

Second, the Withrow Court noted that Murchison did not question the APA. ${ }^{114}$ This is of course true; Murchison did not involve administrative law

110 Withrow, 421 U.S. at 47.

111 Tumey v. Ohio, 273 U.S. 510, 532 (1927).

112 Withrow, 421 U.S. at 53.

113 See infra Section III.A.

114 Withrow, 421 U.S. at 53. 
at all, and it did not involve a challenge to the APA. There was thus no reason for the Court in Murchison to question the validity of the APA or to even mention the APA, nor should it have. But the Murchison Court's failure to question the validity of the APA does not mean that the APA comports with the rule in Murchison or due process generally.

In important ways, for due process purposes, formal administrative hearings are functionally identical to traditional judicial adjudications. Both proceedings involve adversary parties standing before an adjudicator; both proceedings require notice; and both proceedings allow for presentation of evidence and cross-examination. Also, agencies are often empowered to impose sanctions that are as severe as those imposed by courts in civil cases. $^{115}$ They can impose civil penalties, disgorgement of ill-gotten gains, censures, cease and desist orders, and license revocations. ${ }^{116}$ Thus, when due process applies, the same constitutional standards should apply. This means that, above all, the traditional neutral adjudicator requirement should apply, because absent a neutral adjudicator, all other procedural protections are rendered irrelevant.

The Withrow Court implied that in the administrative context the requirements imposed by the APA are synonymous with those imposed by due process. This is shown by the fact that the Court states that it is normal for members of agencies to review investigation results, approve the initiation of charges, and then participate in the adjudication of the claim. ${ }^{117}$ The Court goes on to say, "[t] his mode of procedure does not violate the Administrative Procedure Act, and it does not violate due process of law." 118 The Court appears to suggest that rather than conducting an independent due process analysis of agency action, the Court looks only to whether the APA is violated in order to determine the constitutionality of both state and federal administrative action. The clear implication is that satisfying the APA somehow automatically satisfies due process. But the APA, like any federal statute, is trumped by an inconsistent constitutional directive, and the Court failed to provide any basis for its implicit assumption that the limits imposed by the APA and the Due Process Clause are conterminous.

Like the Mayors in Tumey and Ward, agency commissioners occupy two different positions, one partisan and one judicial. Like the Mayor in Ward, these commissioners may feel pressure to take a hardline position against violators of their directives and maintain a high level of enforcement. By the standard set in Tumey and Ward, it seems clear that allowing commissioners to be directly involved in investigations, prosecutions, and adjudications of the same claim violates due process.

115 In some instances, agencies may enforce their awards only through resort to the judicial process. However, the enforcing courts are required to give significant deference to agency findings of fact.

116 See, e.g., Office of Administrative Law Judges, supra note 61.

117 Withrow, 421 U.S. at 56.

$118 I d$. 
What brings the situations in the administrative context even closer to that in Ward is that these agencies often assess civil money penalties on defendants. Just like the Mayor in Ward, who may be biased because fees from his court financed his executive needs, in the SEC's case, the Commissioners could also be biased because civil money penalties indirectly affect their budget. As we discussed above, ${ }^{119}$ in the SEC, most of the money collected through civil money penalties goes to the U.S. Treasury General Fund, which in turn funds the SEC. ${ }^{120}$ Over the last several years, the SEC has seen a significant increase in its budget. ${ }^{121}$ It seems possible that this increase in the SEC budget could be related to the increase in civil money penalties the SEC contributed to the General Fund, suggesting that civil money penalties could affect the Commissioners' budget. Under Ward, the Commissioners' adjudication of appeals violates due process because there is a "possible temptation" for the Commissioners to assess more civil money penalties in order to increase their budget. ${ }^{122}$

\section{Fixing the Administrative State's Due Process Problem}

A common reaction to our due process critique of the administrative state is likely to be that rectifying these constitutional difficulties, even if one acknowledges their existence, would effectively destroy the administrative state, and it is simply too late in the day to do that. We certainly understand the argument as a purely practical, if not theoretical matter. But we are dubious of any such argument, for it necessarily tolerates the notion that government may violate core notions of constitutional democracy in the name of efficiency. Perhaps more importantly, we are not ready to concede that the modern administrative state cannot coexist with rigorous adherence to the dictates of procedural due process in general and the requirement of a neutral adjudicator in particular. Transformation of the ALJ corps by making them employees of the U.S. government generically, rather than of the particular agency, and significantly increasing their independence could go very far toward improving the adjudicatory neutrality of the administrative process. $^{123}$ If one were also to substantially increase judicial review of agency

119 See supra Section II.A.

120 See supra Section II.A.

121 Since fiscal year 2006, the SEC's budget has nearly doubled, from a budget of $\$ 888,117,000$ in fiscal year 2006 , to a budget of $\$ 1,652,000,000$ in fiscal year 2018. Budget History-BA vs. Actual Obligations, U.S. SEc. \& Exchange Comm'n, https://www.sec.gov/ foia/docs/budgetact.htm (last modified June 9, 2017).

122 Tumey v. Ohio, 273 U.S. 510, 532 (1927).

123 For a thorough discussion of the serious problems currently plaguing administrative law judges because of their lack of independence, see Kent Barnett, Against Administrative Judges, 49 U.C. Davis L. Rev. 1643, 1648 (2016) [hereinafter Barnett, Against Administrative Judges], and Kent Barnett, Resolving the ALJ Quandary, 66 VAND. L. REv. 797 (2013). In Professor Barnett's words, "[t] he key problem with all agency hearings . . . is that they create inherent partiality concerns. The adjudicator's employing agency is often a party and controls the adjudicator's budget and perhaps salary. Indeed, the agency may even 
decisions - a move, we understand, that would be viewed with alarm by supporters of the current system-the revised system could arguably satisfy due process. And it should always be kept in mind that none of our constitutional concerns extends to the rulemaking authority of administrative agencies.

For the remainder of this Article we are willing to proceed on the assumption that for whatever reason, our broad constitutional challenge to the administrative process has been categorically rejected. Even in the face of such wholesale rejection, we believe that one may reasonably confine the reach of our constitutional attack to enclaves consisting of situations where the dangers caused by the absence of adjudicatory neutrality are especially pathological. In so doing, we would be able to remove the most serious due process dangers while at the same time leaving the bulk of the administrative state unchanged. ${ }^{124}$ It is therefore to an analysis of these narrower alternatives that we now turn.

\section{Avoiding the Most Serious Due Process Pathologies of the Administrative State}

To this point, we have established that procedural due process and its requirement of a neutral adjudicator should be seen to raise serious constitutional problems concerning the adjudicatory power exercised by administrative agencies. Even when prosecutorial and adjudicatory powers are not combined in the same administrators, the fact remains that those who make the ultimate decision are still part of the very same agency that has instituted the enforcement proceeding in the first place. Problems of motivated reasoning and cognitive dissonance plague the administrative decision-making process, threatening adjudicatory neutrality. ${ }^{125}$ As serious as these concerns are, however, for reasons to be explained they expand geometrically when the relevant issues of fact and law involve not merely the application of administrative regulation to the particular behavior of regulated private actors, but rather to the legitimacy of constitutional challenges to agency regulatory authority or action. And those constitutional concerns, in turn, become almost infinitely more problematic in one specific context: when the constitutional challenge is grounded in the First Amendment right of free expression.

present expert witnesses who are the adjudicator's own co-workers." Barnett, Against Administrative Judges, supra at 1648.

124 We should emphasize that we do so while simultaneously adhering to our position that the entire administrative process, as currently structured, is constitutionally tainted, requiring significant revision to satisfy the requirements of procedural due process. See supra Sections II.B-C.

125 See supra Section II.B. 


\section{A. Adjudicatory Neutrality and Constitutional Challenges to Agency Authority}

The venerable doctrine of constitutional fact ${ }^{126}$ evinces fundamental mistrust of the ability of agencies to judge constitutional challenges to their authority, and with good reason. We have already explained why administrators whose very purpose is to regulate would likely have great difficulty maintaining objectivity in deciding between the claims of fellow agency members seeking to regulate and the private actor opposing regulation. ${ }^{127}$ The problem of maintaining objectivity is far greater when an external constitutional challenge to the exercise of agency authority is presented. In such a situation, the scope of an agency's authority to act has been attacked on the basis of what are claimed to be restraints imposed by sources external to that agency. While courts are on occasion called upon to rule upon the constitutionality of their own authority, ${ }^{128}$ their objectivity is generally not threatened in the same way as that of agency decisionmakers. Judges of state or federal courts are aware that as a practical matter, their general jurisdiction will remain in existence, regardless of whatever individualized tweaking takes place. The same cannot be said of agency decisionmakers, whose authority to act does not reach as broadly and is more fragile. Moreover, to the extent a similar danger might be thought to arise in the judicial context, the doctrine of necessity, grounded in the need to preserve separation of powers, will usually justify vesting final say as to the constitutionality of restrictions on judicial authority in the hands of the courts themselves. Any other result would leave judicial jurisdiction dangerously vulnerable to a form of political guerrilla warfare, designed to emasculate the courts as protectors of countermajoritarian constitutional rights and values. The same rationale in no way justifies deference to administrative determination of issues of fact or law on which the constitutionality of their exercise of authority turns.

For the most part, a categorical exclusion of judicial deference to agency factfinding on constitutional challenges is already doctrinally precluded by the constitutional fact doctrine. To the extent we are seeking doctrinal alteration, it would be to demand a reinvigoration and clarification of the under-

126 The doctrine finds its modern origins in the Supreme Court's decision in Ohio Valley Water Co. v. Ben Avon Borough, 253 U.S. 287 (1920), concerning a constitutional challenge to a rate set by a state regulatory commission. The decision most closely associated with it is Crowell v. Benson, 285 U.S. 22, 65 (1932), where the Court held that factual determinations related to factual issues that determined the constitutionality of federal legislation had to be decided de novo by the courts. It has been incorrectly suggested that the doctrine no longer exists, see Martin H. Redish et al., Federal Courts: Cases, Comments AND QUestions 213 (7th ed. 2012) (compiling authorities), but that is for the most part because the specific constitutional issues on which Crowell turned are for the most part no longer viable. See Martin H. Redish, Federal Jurisdiction: Tensions in the Allocation of Judicial Power 51-52, 138-47 (2d ed. 1990). Something akin to the doctrine was invoked as recently as the Court's decision in Hamdi v. Rumsfeld, 542 U.S. 507, 509 (2004). For a discussion of the general issue, see Martin H. Redish \& William D. Gohl, The Wandering Doctrine of Constitutional Fact, 59 ArIz. L. REv. 289 (2017).

127 See supra Section II.A.

128 See, e.g., In re Murchison, 349 U.S. 133 (1955). 
lying rationale of such a doctrine. ${ }^{129}$ As problematic as is the general exercise of agency authority to make legal or factual determinations on which the constitutionality of agency authority turns, far more troublesome is an agency's exercise of such authority when that constitutional challenge is grounded in the First Amendment right of free expression. It is therefore to an analysis of this unique context that we now turn.

\section{B. The Special Case of First Amendment Due Process}

That due process takes on a special quality when the First Amendment right of free expression is at stake is demonstrated by the recognition of a doctrine known as "First Amendment due process." 130 To understand the unique aspects of First Amendment due process, it is first necessary to explore the concept's theoretical and doctrinal foundations and development. This Section will therefore explore both, and in so doing underscore both the unique aspects of the due process issues in the context of the First Amendment and how the current administrative adjudicatory structure must be altered in order to preserve both First Amendment and due process rights of those parties regulated by the administrative process.

\section{The Concept and Origins of First Amendment Due Process}

In the mid-1960s, the Supreme Court began to develop a special procedural due process doctrine for cases involving First Amendment rights. In Freedman v. Maryland ${ }^{131}$ the Court held unconstitutional a Maryland censorship statute, reasoning that "a noncriminal process which requires the prior submission of a film to a censor avoids constitutional infirmity only if it takes place under procedural safeguards designed to obviate the dangers of a censorship system."132 The Court emphasized that "because only a judicial determination in an adversary proceeding ensures the necessary sensitivity to freedom of expression, only a procedure requiring a judicial determination suffices to impose a valid final restraint."133 Professor Henry Monaghan, in his seminal article on the subject, explained the Court's conclusion, noting that the administrative censor does not play the role of "the impartial adjudicator but that of the expert-a role which necessarily gives an administrative agency a narrow and restricted viewpoint. . . Courts, on the other hand, do not suffer congenitally from this myopia; their general jurisdiction gives them a broad perspective which no agency can have." 134 The Maryland statute, the Court concluded, "provides no assurance of prompt judicial determination." 135

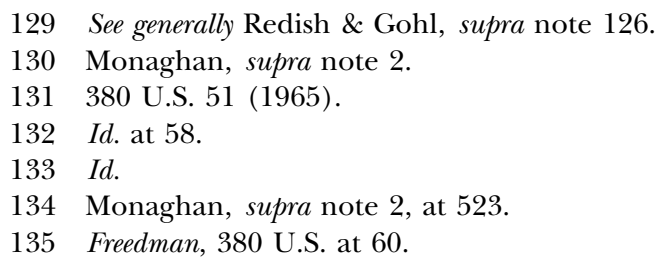


Unfortunately, the Freedman Court left ambiguous exactly what should be considered "prompt judicial determination.” Justice Brennan's opinion indicated that the censor must, "within a specified brief period, either issue a license or go to court to restrain showing the film." ${ }^{36}$ But immediately after this sentence, he wrote the following: "Any restraint imposed in advance of a final judicial determination on the merits must similarly be limited to preservation of the status quo for the shortest fixed period compatible with sound judicial resolution." 137 He thus appeared to acknowledge the possibility of the imposition of a nonjudicial restraint on expression while the judicial determination of the constitutionality of the restraint proceeded. ${ }^{138}$

If this is in fact what Justice Brennan intended to say, the statement would represent a total departure from the reasoning underlying the rest of the opinion. The Court recognized the dangers of an interim restraint on speech. The simple fact is that an interim restraint is a restraint for however long it lasts, and therefore constitutes a prima facie violation of the First Amendment's free speech guarantee. The Court gave no reason why such interim restraints pending final judicial resolution cannot be given by a court, rather than the administrator. Indeed, the Court's opinion made clear that administrative restraint of speech never satisfies the dictates of First Amendment due process, so why-at least in the absence of some emergency where a court is somehow not immediately available-should not the interim restraints, much like the final restraints, be imposed by a court through issuance of either preliminary injunctions or temporary restraining orders? It appears, then, that the Court in Freedman did not think through the inescapable logical implications of its own premises. Nevertheless, it is important not to undervalue the significance of Freedman in understanding the special status of the First Amendment in the context of procedural due process in general or adjudicatory neutrality in particular. As important as adjudicatory neutrality is to procedural due process in any context, Freedman underscores its unique status when First Amendment rights are at stake.

There are three reasons for the special status of First Amendment due process. The first reason is, simply, the special status of free expression in our system of constitutional liberties. In contrast, in most administrative adjudications the stakes involve solely property rights-important and worthy of protection by procedural due process guarantees to be sure, but not presently considered to rise to the level of constitutional significance of the right of free expression. As a famous free speech scholar once wrote: "The principle of the freedom of speech springs from the necessities of the program of self-government. . . . It is a deduction from the basic American agreement that public issues shall be decided by universal suffrage."139 Absent free

$136 I d$. at 59.

137 Id. (emphasis added).

138 It is true that on its face, this sentence could also be construed to refer solely to judicially imposed interim restraints. In context, however, it is more likely that Justice Brennan was referring to administratively imposed interim restraints.

139 Alexander Meiklejohn, Political Freedom 27 (1960). 
expression, self-government-whether on the collective or individual levels ${ }^{140}$ - cannot function effectively. Therefore, greater procedural protection should be required before administrators are permitted to interfere with the right of free expression. The second reason is the consequential significance of the constitutionally pathological interim restraint resulting from administrative adjudication, even if sweeping judicial review is to be followed. If, as the Court in Freedman correctly recognized, when rights of free expression are at stake, due process is judicial process, and any restraint imposed by an administrative body is inherently suspect-especially because a constitutional challenge to its authority challenges the very validity of regulatory power. The third reason concerns the unique dangers of a chilling effect, which have been widely recognized in the First Amendment context. ${ }^{141}$ Indeed, the Court in Freedman pointed to the concern about a chilling effect in recognizing the importance of prompt judicial action. ${ }^{142}$

\section{Altering Federal Administrative Procedure in Light of First Amendment Due Process}

Despite the venerable existence of the First Amendment due process doctrine, it appears to this point to have played no role at all in shaping federal administrative procedure. This should not be surprising, in light of the Court's bizarre, unfounded assumption, expressed in Withrow, that agency compliance with the APA somehow automatically signals compliance with the dictates of the Constitution. ${ }^{143}$ At some point in law school, if not before, the Justices should have learned that the Constitution controls federal statutes, not the other way around, and to the extent a statute departs from constitutional dictates it is invalid.

140 See Martin H. Redish, The First Amendment in the Marketplace: Commercial Speech and the Values of Free Expression, 39 GEO. WASH. L. REv. 429 (1971) (recognizing concept of "private” self-government as justification for extending First Amendment protection to commercial speech).

141 See, e.g., N. Y. Times Co. v. Sullivan, 376 U.S. 254 (1964) (expressing concern about possible chilling effect as partial justification for adoption of "actual malice" test as a First Amendment protection for defamation of public officials).

142 The Freedman Court noted that a prompt judicial decision was needed "to minimize the deterrent effect of an interim and possibly erroneous denial" of free speech rights. Freedman, 380 U.S. at 59. It has been suggested that the concern about the chilling effect has no place in the regulation of commercial speech, since the profit motive will always incentivize the speaker, regardless of the fears of regulation. See, e.g., Robert Post \& Amanda Shanor, Adam Smith's First Amendment, 128 HaRv. L. Rev. F. 165, 169-70 (2015) (relying on the decision in Central Hudson Gas E Electric Corp. v. Public Service Commission, 447 U.S. 557 (1980)). In reality, the exact opposite is likely to be true; for the very reason of the profit incentive, commercial speakers may well behave in a risk-averse manner in an attempt to avoid liability or regulatory penalty. The issue is not whether the commercial speaker will speak, but whether it will be deterred from communicating what might well prove to be valuable information out of fear of regulatory liability.

143 See supra Section II.C. 
There is much to be learned from a synthesis of our analyses of adjudicatory neutrality, procedural due process, and the special role played by the First Amendment in our constitutional system. First, administrators are constitutionally incapable of exercising final or even presumptive power to determine the constitutionality of their proposed regulation or authority in the presence of a First Amendment challenge. ${ }^{144}$ This is so, even if an agency formally separates prosecutorial and adjudicatory functions. While such a formal separation could arguably satisfy due process concerns in the case of subconstitutional adjudications (for example, in adjudications designed to determine whether a party's behavior has in fact violated an agency regulation or order), when a constitutional challenge to agency authority has been raised to agency action the inherent defensiveness of an administrator in favor of her agency and its powers gives rise to fatal constitutional problems of insufficient neutrality.

Second, in the context of First Amendment challenges, delaying judicial review until the close of the administrative process violates First Amendment rights because of the interim restraint that has been administratively imposed pending judicial review. Third, even in the absence of an administratively imposed interim restraint, delaying judicial adjudication of First Amendment challenges to administrative action until completion of an administrative process should be deemed to violate First Amendment due process. The "deterrent" effect pointed to by the Court in Freedman should be recognized as raising a sufficiently serious concern that an individual or entity that is subjected to a complex administrative process before it can even raise its First Amendment challenge would deter the individual or entity from even seeking to engage in the expressive activity in the first place. The delay of judicial review of a First Amendment challenge until a subconstitutional administrative process has been completed surely cannot satisfy Freedman's requirement of "prompt" judicial action.

It has been widely thought that the chilling effect concern should play no role in the context of commercial speech. ${ }^{145}$ This conclusion is ironic, since the Court in Freedman found that the economic calculations of the film business might well deter them from speaking. ${ }^{146}$ The Freedman Court's insight is logically applicable as much in the context of commercial speech as it is to the film businesses in Freedman. It is reasonable to assume that economic calculations are more likely to deter a would-be corporate speaker than they are to deter a speaker motivated by ideological belief rather than economic gain.

Acceptance of our conclusions would require dramatic alteration in existing doctrine. That doctrine is best illustrated by the decision of the

144 On this one point, it should be noted, First Amendment challenges do not differ from other constitutional challenges.

145 See, e.g., Va. State Bd. of Pharmacy v. Va. Citizens Consumer Council, Inc., 425 U.S. 748, 771 n.24 (1976) ("[T]here is little likelihood of [commercial speech] being chilled by proper regulation .....”); Post \& Shanor, supra note 142, at 169.

146 See Freedman, 380 U.S. at 59. 
United States District Court for the District of Columbia in POM Wonderful $L L C v . F T C .{ }^{147}$ There the plaintiff, the largest processor and distributor of pomegranate products in the United States, sought a declaratory judgment that the FTC's new rule governing disease claims in food advertising exceeds the Agency's authority and violates the plaintiff's First and Fifth Amendment rights. The FTC moved to dismiss the complaint, and the court granted the motion. One of the primary factors leading to the dismissal was the fact that granting declaratory relief would require the resolution of an anticipatory defense. ${ }^{148}$ The court quoted the Eighth Circuit's decision in BASF Corp. $v$. Symington: "[W]here a declaratory plaintiff raises chiefly an affirmative defense, and it appears that granting relief could effectively deny an allegedly injured party its otherwise legitimate choice of the forum and time for suit, no declaratory judgment should issue." 149 The court in POM concluded that "[c]ourts should not allow parties to use the Declaratory Judgment Act to engage in forum shopping," 150 and that "[y]ielding here while the administrative action proceeds will not significantly prejudice POM." ${ }^{151}$

While the POM court's conclusion is consistent with the general rule on the subject of declaratory judgments seeking to raise an anticipatory defense, ${ }^{152}$ to apply the same logic to First Amendment challenges to administrative action is grossly inconsistent with both the spirit and letter of the Supreme Court's First Amendment due process doctrine. Where First Amendment rights are at stake, as they were in POM, for the reasons developed throughout this Article it is simply wrong to conclude that the party asserting a First Amendment claim will not suffer significant prejudice by delaying its ability to raise its constitutional challenge until completion of the administrative process. Moreover, the logic traditionally relied upon to prohibit such anticipatory actions-that "[c] ourts should not allow parties to use the Declaratory Judgment Act to engage in forum shopping"153_is wholly irrelevant in the context of a First Amendment challenge to administrative action. We are not faced with a situation involving two private parties where the defendant is attempting to gain a strategic forum advantage over the plaintiff who chose the original forum. We are faced, rather, with the question of whether or not First Amendment due process will allow an agency to drain a private litigant of its resources, deterring it from continuing its constitutional challenge, by placing substantial procedural hurdles in its way that significantly delay its ability to have its First Amendment claim adjudicated in a judicial forum. To satisfy the requirements of First Amendment due process, then, the doctrine enunciated by the district court in POM must be rejected in the specific context of a First Amendment challenge to adminis-

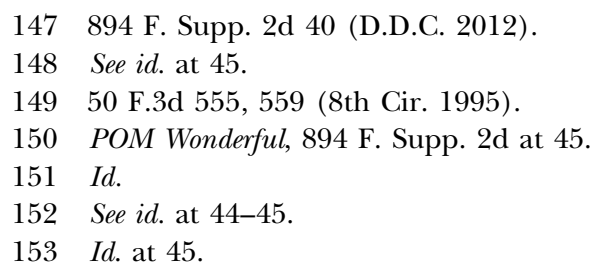


trative agency action. A subject of regulation who possesses a plausible First Amendment claim ${ }^{154}$ must, as a matter of First Amendment due process, be permitted to stay the administrative regulatory proceeding and seek declaratory relief on its First Amendment claim in federal court.

\section{Conclusion: Procedure as the Handmaid of Justice}

As foundational to constitutional democracy as substantive constitutional rights clearly are, their protections would be meaningless absent the simultaneous existence of meaningful procedural devices by which those rights are effectively implemented and protected. As Judge Charles Clarkthe father of the Federal Rules of Civil Procedure-once wrote, procedure is "the handmaid of justice." 155 This substantive-procedural intersection is nowhere more important than in the context of challenges to the exercise of governmental regulatory authority on the grounds of the First Amendment right of free expression. The primacy of that right is widely recognized, and for this reason the intersection of substance and procedure has been explicitly recognized by the Supreme Court in its doctrine of First Amendment due process. ${ }^{156}$

In this Article, we have argued that First Amendment due process is especially in peril in the context of the federal administrative state. For that reason, we urge dramatic changes in administrative process. While significant changes are both necessary and important in all contexts, they are of special importance when First Amendment rights are at stake, due to their widely recognized unique importance to the preservation of constitutional democracy and their inherent fragility. When First Amendment rights are at stake, the role of the administrator must be significantly reduced, and the role of the reviewing court correspondingly increased. Absent such dramatic changes, the administrative process seriously endangers all-important rights of free expression.

154 A litigant who raises a frivolous First Amendment claim for purposes of delay is subject to sanctions pursuant to Rule 11 of the Federal Rules of Civil Procedure. Fed. R. Crv. P. 11.

155 Charles E. Clark, The Handmaid of Justice, 23 WASH. U. L.Q. 297 (1938).

156 See Freedman v. Maryland, 380 U.S. 51 (1965); supra notes 143-46 and accompanying text. 